\title{
Solubilization of an Adenosine Uptake Site in Brain
}

\author{
Ajay Verma, Michelle Houston, and Paul J. Marangos \\ Unit on Neurochemistry. Biological Psychiatry Branch, National Institute for Mental Health, \\ Bethesda, Maryland. U.S.A.
}

\begin{abstract}
Procedures are described for the solubilization of adenosine uptake sites in guinea pig and rat brain tissue. Using $\left[{ }^{3} \mathrm{H}\right]$ nitrobenzylthioinosine $\left(\left[{ }^{3} \mathrm{H}\right] \mathrm{NBI}\right)$ the solubilized site is characterized both kinetically and pharmacologically. The binding is dependent on protein concentration and is saturable, reversible, specific, and high affinity in nature. The $K_{\mathrm{D}}$ and $B_{\max }$ of guinea pig extracts are $0.13 \pm 0.02 \mathrm{n} M$ and $133 \pm 18 \mathrm{fmol} / \mathrm{mg}$ protein, respectively, with linear Scatchard plots obtained routinely. Similar kinetic parameters are observed in rat brain. Adenosine uptake inhibitors are the most potent inhibitors of $\left[{ }^{3} \mathrm{H}\right] \mathrm{NBI}$ binding with the following order of potency, dilazep $>$ hexobendine $>$ dipyridamole. Adenosine receptor ligands are much less potent inhibitors of binding, and caffeine is without effect. The solubilized adenosine uptake site is, therefore, shown to have virtually identical properties to the native membrane site. The binding of the adenosine $A_{1}$ receptor agonist
\end{abstract}

$\left[{ }^{3} \mathrm{H}\right]$ cyclohexyladenosine $\left(\left[{ }^{3} \mathrm{H}\right] \mathrm{CHA}\right)$ to the solubilized brain extract was also studied and compared with that of $\left[{ }^{3} \mathrm{H}\right] \mathrm{NBI}$. In contrast to the $\left[{ }^{3} \mathrm{H}\right] \mathrm{NBI}$ binding site $\left[{ }^{3} \mathrm{H}\right] \mathrm{CHA}$ binds to two apparent populations of adenosine receptor, a high-affinity site with a $K_{\mathrm{D}}$ of $0.32 \pm 0.06 \mathrm{n} M$ and a $B_{\max }$ of $105 \pm 30 \mathrm{fmol} / \mathrm{mg}$ protein and a loweraffinity site with a $K_{\mathrm{D}}$ of $5.50 \pm 0.52 \mathrm{n} M$ and $B_{\max }$ of 300 $\pm 55 \mathrm{fmol} / \mathrm{mg}$ protein. The pharmacology of the $\left[{ }^{3} \mathrm{H}\right] \mathrm{CHA}$ binding site is consistent with that of the adenosine receptor and quite distinct from that of the uptake $\left(\left[{ }^{3} \mathrm{H}\right] \mathrm{NB}\right]$ binding) site. Therefore, we show that the adenosine uptake site can be solubilized and that it retains both its binding and pharmacologic properties in the solubilized state. Key Words: Solubilized adenosine uptake sitesNitrobenzylthioinosine-Adenosine receptors. Verma A. et al. Solubilization of an adenosine uptake site in brain. J. Neurochem. 45, 596-603 (1985).
Adenosine and several of its metabolically stable analogs, such as cyclohexyladenosine ( $\mathrm{CHA}$ ) and L-phenylisopropyladenosine (L-PIA), have been found to exert potent effects on nervous tissue activity. These compounds depress nerve cell firing (Phillis et al., 1979), inhibit the stimulus-evoked release of several neurotransmitters (Fredholm and Hedquist, 1980), modulate adenylate cyclase activity (Daly, 1979; Van Calker et al., 1979; Patel et al., 1981), and induce sedation when administered in vivo (Haulica et al., 1973; Crawley et al., 1982).

Adenosine is released in a depolarization-induced, calcium-dependent manner (Stone, 1981) and its effects are thought to be mediated by specific, high-affinity, cell-surface recognition sites that have been described in brain using radiolabeled stable adenosine analogs (Bruns et al., 1980; Patel et al., 1982a). Termination of adenosine action is thought to be regulated primarily by a facilitated reuptake mechanism involving specific elements in the cell membrane (Paterson, 1979; Bender et al., 1980; Barberis et al., 1981). The activity of this adenosine uptake mechanism is important since agents that inhibit this process have been shown to potentiate the neuromodulatory effects of adenosine (Huang and Daly, 1974; Phillis et al.. 1979; Crawley et al., 1983; Phillis and Wu, 1983a). Inhibition of adenosine uptake in peripheral tissue is thought to be the mechanism of action of vasoactive drugs such as dilazep and dipyridamole (Sano, 1974). Such an inhibition may also be partially responsible for the actions of centrally active drugs such as benzodiazepines and phenothiazines (Phillis and $\mathrm{Wu}, 1983 a$ ).

Recent investigations examining adenosine uptake sites directly have employed binding studies using $\left[{ }^{3} \mathrm{H}\right]$ nitrobenzylthioinosine $\left(\left[{ }^{3} \mathrm{H}\right] \mathrm{NBI}\right)$, which is a potent, selective inhibitor of adenosine uptake
Received October 30, 1984; accepted February 11. 1985.

Address correspondence and reprint requests to Dr. P. J. Marangos at Unit on Neurochemistry, BPB, Bldg. 10. Room 3C210, Bethesda, Maryland 20205, U.S.A.
Abbreviations used: CHA. cyclohexyladenosine; NBI, nitrobenzylthioinosine; L-PIA, L-phenylisopropyladenosine; PMSF, phenylmethylsufonyl fluoride. 
into both nervous (Barberis et al., 1981) and nonnervous tissue (Pickard and Paterson, 1972; Brajeswar et al., 1975). $\left[{ }^{3} \mathrm{H}\right] \mathrm{NBI}$ has been shown to bind specifically, reversibly, and with high affinity to adenosine uptake sites in erythrocytes (Jarvis and Young, 1980), HeLa cells (Lauzon and Paterson, 1977), and brain (Marangos et al., 1982). Hammond et al., in studies using human erythrocytes (Hammond et al., 1982) and guinea pig cortical tissue (Hammond and Clanachan, 1982, 1983), have shown that displacement of $\left[{ }^{3} \mathrm{H}\right] \mathrm{NBI}$ binding by a test compound was indicative of that compound's ability to block adenosine uptake into these tissues. Thus, the measurement of site-specific binding of $\left[{ }^{3} \mathrm{H}\right] \mathrm{NBI}$ seems to offer a convenient probe for studying molecular interactions at adenosine uptake sites just as the stable radioactive adenosine analogs do for adenosine receptors.

One of the fundamental approaches in understanding the biochemistry of these membranebound sites is their solubilization in a functional state. Several recent studies have used this approach to examine adenosine receptors in brain (Gavish et al., 1982; Bruns et al., 1983; Nakata and Fujisawa, 1983). Using $\left[{ }^{3} \mathrm{H}\right] \mathrm{NBI}$ and cyclohexyl $\left[{ }^{3} \mathrm{H}\right]$ adenosine $\left(\left[{ }^{3} \mathrm{H}\right] \mathrm{CHA}\right)$ as probes, we now report successful solubilization of both adenosine uptake sites and receptors from guinea pig brains. $\left[{ }^{3} \mathrm{H}\right] \mathrm{NBI}$-labeled uptake sites are characterized and are seen to retain pharmacological and binding kinetic properties similar to those described in membrane bound preparations.

\section{MATERIALS AND METHODS}

\section{Membrane preparation}

Frozen rat or guinea pig whole brains were suspended in 10 volumes of cold $50 \mathrm{mM}$ Tris- $\mathrm{HCl}$ buffer ( $\mathrm{pH} 7.5$ ) containing $10 \mathrm{~m} M$ EDTA, $100 \mathrm{M}$ phenylmethysulfonyl fluoride (PMSF), and $1 \mathrm{mM}$ 1,10-phenathroline using a Brinkman Polytron (speed 5 for 30 s). The suspension was centrifuged at $30,000 \mathrm{~g}$ for $20 \mathrm{~min}$ and the resulting pellets were suspended in 10 volumes of $50 \mathrm{~m} M$ Tris- $\mathrm{HCl}(\mathrm{pH}$ 7.5 ) and spun again as above. The following pellets were resuspended in Tris buffer and incubated with $2 \mathrm{U} / \mathrm{ml}$ of adenosine deaminase at room temperature for $30 \mathrm{~min}$. The suspensions were centrifuged again and the final pellets were stored at $-70^{\circ} \mathrm{C}$. Pellets thus stored were found to be stable for several weeks.

\section{Detergent solubilization}

Solubilization of membrane pellets was accomplished using the method described by Bruns et al. for solubilizing various receptors (Bruns et al., 1983). Briefly, $1 \mathrm{~g}$ (tissue wet weight) of membrane pellet was thawed and suspended in 20 volumes of $50 \mathrm{mM}$ Tris- $\mathrm{HCl}$ and centrifuged at $30,000 \mathrm{~g}$ for $20 \mathrm{~min}$. Using a pasteur pipet, the washed pellet was finely resuspended in $2 \mathrm{ml}$ of solubilization buffer containing $10 \mathrm{~m} M$ Tris- $\mathrm{HCl}, 1 \mathrm{~m} M$ dithiothreitol (DTT), and either $20 \%$ glycerol or no glycerol at $0^{\circ} \mathrm{C}$. Two milliliters of solubilization buffer with $1 \%$ CHAPS deter- gent was added, and the suspension was swirled gently for $30 \mathrm{~s}$ and centrifuged at $145,000 \mathrm{~g}$ for $\mathrm{l} \mathrm{h}$ in a Beckman L.8-55 ultracentrifuge using a 45-Ti rotor. The supernatant was removed with a pasteur pipet and passed through a Millipore $0.22 \mu M$ filter. The filtrate was either assayed directly for binding or stored at $-20^{\circ} \mathrm{C}$. To test the effect of glycerol on stability of the solubilized extracts, the preparation extracted without any glycerol was adjusted to contain either 5 or $20 \%$ glycerol. Subsequently, all binding experiments were done with supernatant that had been adjusted to contain $20 \%$ glycerol after the extraction.

\section{$\left[{ }^{3} \mathrm{H}\right] \mathrm{NBI}$ binding assay}

Solubilized extracts $(0.3-0.4 \mathrm{mg}$ of protein) were incubated in the presence of $\left[{ }^{3} \mathrm{H}\right] \mathrm{NBI}(17 \mathrm{Ci} / \mathrm{mmol}, \mathrm{Mo}$ ravek Biochem) in $50 \mathrm{~m} M$ Tris- $\mathrm{HCl}$ buffer ( $\mathrm{pH} \mathrm{7.4)} \mathrm{(final}$ volume of $0.5 \mathrm{ml}$ ) for $30 \mathrm{~min}$ at $22^{\circ} \mathrm{C}$. Assays were terminated by rapid vacuum filtration through Whatman GF$B$ filters that had been presoaked for $1-24 \mathrm{~h}$ in $0.3 \%$ polyethylenimine (Sigma). The filters were subsequently washed quickly with $4 \times 3 \mathrm{ml}$ washes of ice-cold Tris buffer. Filters were air-dried and counted in $10 \mathrm{ml}$ of Redi-Solv scintillation fluid (Beckman). Nonspecific binding was determined by adding $5 \mu M$ NBI (Calbiochem) in the assay and routinely represented $10 \%$ or less of the total binding at $0.7 \mathrm{nM}\left[{ }^{3} \mathrm{H}\right] \mathrm{NBI}$. Specific binding was determined by subtracting the nonspecific binding values from total binding values. Scatchard analyses were performed by incubating the soluble extracts with $\left[{ }^{3} \mathrm{H}\right] \mathrm{NBI}$ concentrations ranging from 0.05 to $2.5 \mathrm{nM}$. Inhibition studies were done by incubating the extracts in the presence of six different concentrations of inhibitor and $0.7 \mathrm{n} M\left[{ }^{3} \mathrm{H}\right] \mathrm{NBI}$. All binding data are expressed as specific binding and all assays were performed in triplicate. $K_{\mathrm{I}}$ values were calculated using the relationship $K_{\mathrm{I}}$ $=\mathrm{IC}_{50} /\left(1+[\mathrm{L}] / K_{\mathrm{D}}\right)$

\section{$\left[{ }^{3} \mathrm{H}\right] \mathrm{CHA}$ binding assay}

$\left[{ }^{3} \mathrm{H}\right] \mathrm{CHA}$ binding to soluble extracts was measured in a manner similar to that described above for $\left[{ }^{3} \mathrm{H}\right] \mathrm{NBI}$ binding, except that the incubation was performed at $22^{\circ} \mathrm{C}$ for $2 \mathrm{~h}$. Nonspecific binding was determined by incorporating $50 \mu M \mathrm{CHA}$ (Calbiochem). Scatchard analysis was performed by incubating extracts with $\left[{ }^{3} \mathrm{H}\right] \mathrm{CHA}(25$ $\mathrm{Ci} / \mathrm{mmol}$ ) concentrations ranging from 0.40 to $25.0 \mathrm{n} M$. Inhibition studies were done using $5 \mathrm{nM}\left[{ }^{3} \mathrm{H}\right] \mathrm{CHA}$. For calculating $K_{\mathrm{I}}$ values the $K_{\mathrm{D}}$ value for $\left[{ }^{3} \mathrm{H}\right] \mathrm{CHA}$ binding was taken as $1 \mathrm{n} M$ rather than using the component highand low-affinity $K_{\mathrm{D}}$ values. All protein determinations were done using the Biorad protein assay.

Verapamil was a gift of Knoll Pharmaceuticals and nimodipine of Miles Pharmaceuticals. In experiments utilizing nimodipine, procedures were performed in darkened rooms. Dilazep was a gift of Hoffmann La Roche (Nutley), CHA was obtained from Calbiochem, and LPIA and all other chemicals used were obtained from Sigma.

\section{RESULTS}

\section{Binding characteristics}

The site-specific binding of $\left[{ }^{3} \mathrm{H}\right] \mathrm{NBI}$ to soluble extractions from guinea pig and rat brains was proportional to the protein concentration in the assay over the range of $0.04-0.60 \mathrm{mg}$ protein $/ \mathrm{ml}$ as shown 
in Fig. 1. Saturation of binding was achieved above a protein concentration of $0.60 \mathrm{mg} / \mathrm{ml}$. In all experiments performed, final protein concentrations ranged between 0.30 and $0.40 \mathrm{mg} / \mathrm{ml}$.

Figure 2 shows the effect of glycerol in stabilizing the activity of solubilized guinea pig extractions. Preparations extracted with $20 \%$ glycerol in the solubilization buffer and those that were reconstituted with $20 \%$ glycerol after extraction in glycerol-free buffer showed no loss of specific binding activity over a 2 -week period. Reconstituting glycerol-free extractions with $5 \%$ glycerol led to a loss of about $30 \%$ of the initial specific binding after a 2-week period. In the absence of glycerol, preparations were found to retain only $50 \%$ of the initial specific binding after 1 week and after 2 weeks almost $90 \%$ of the activity was lost. Preparations extracted with $20 \%$ glycerol included in the solubilization buffer were cloudy or translucent in appearance, even after filtration through $0.22-\mu \mathrm{m}$ filters whereas the preparations to which glycerol was added only after the extraction procedure were completely clear (data not shown).

The time course for the association and dissociation of $\left[{ }^{3} \mathrm{H}\right] \mathrm{NBI}$ binding to guinea pig brain solubilized extractions is shown in Fig. 3a. The specific binding of $0.45 \mathrm{n} M\left[{ }^{3} \mathrm{H}\right] \mathrm{NBI}$ was $50 \%$ complete after approximately 3 min and the binding reaction equilibrium was attained by $20 \mathrm{~min}$. The observed forward rate constant $\left(k_{\text {obs }}\right)$ calculated from the slope of the line in Fig. 3b was $0.143 \mathrm{~min}^{-1}$ and the dissociation rate constant $\left(k_{-1}\right)$, obtained from the slope of the line in Fig. $3 c$ was $0.046 \mathrm{~min}^{-1} . K_{\mathrm{l}}$, as determined using the equation $K_{\mathrm{I}}=\left(k_{\mathrm{obs}}-k_{-1}\right) /$ $\left(\left[{ }^{3} \mathrm{H}\right] \mathrm{NBI}\right)$ (Williams et al., 1976), was $2.2 \times 10^{8}$ $\min ^{-1} M^{-1}$. An estimate of the equilibrium dissociation constant $\left(K_{\mathrm{D}}\right)$ obtained as the ratio $k_{-1} / k_{1}$ was $0.21 \mathrm{n} M$.

The saturation isotherm and Scatchard analysis of $\left[{ }^{3} \mathrm{H}\right] \mathrm{NBI}$ binding to soluble guinea pig brain ex-

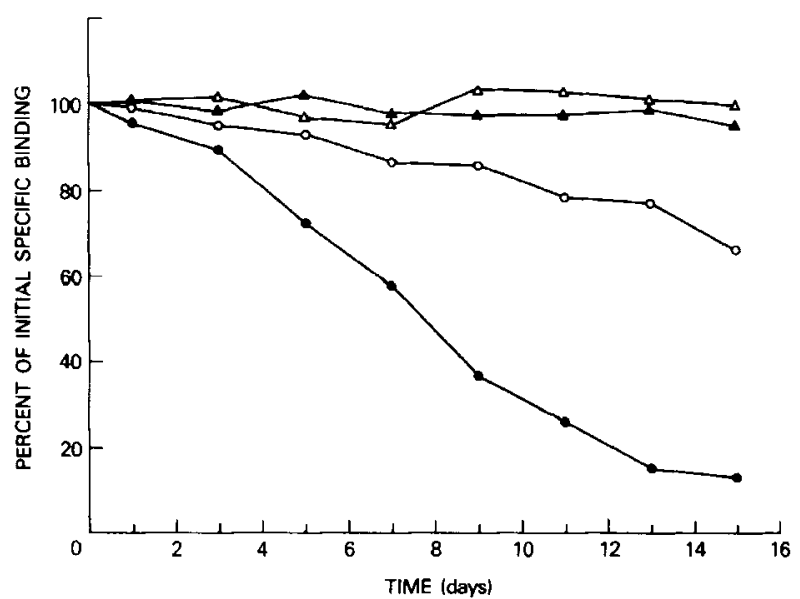

FIG. 2. Effect of glycerol on the stability of $\left[{ }^{3} \mathrm{H}\right] \mathrm{NBI}$ binding to soluble guinea pig brain extracts. Preparations were extracted with $(\Delta)$ and without $20 \%$ glycerol present in the solubilization buffer. Those extracted without any glycerol were reconstituted with either $0 \%(-), 5 \%(O)$, or $20 \%(\Delta)$ glycerol after extraction and stored in aliquots at $-20^{\circ} \mathrm{C}$. Assays for specific binding were done as described in Materials and Methods for 2 weeks. Each point reflects the percent initial (day 0 ) specific binding remaining after various storage times. The experiment was repeated twice with similar results.

tracts are shown in Fig. 4. The specific binding was saturable with an apparent $K_{\mathrm{D}}$ of $0.13 \pm 0.02 \mathrm{nM}$ and $B_{\max }$ value of $150 \pm 35 \mathrm{fmol} / \mathrm{mg}$ protein. Similar plots were obtained in examining $\left.{ }^{3} \mathrm{H}\right] \mathrm{NBI}$ binding to soluble extracts from rat brain with a $K_{\mathrm{D}}$ value of $0.12 \pm 0.03 \mathrm{nM}$ and $B_{\max }$ of $133 \pm 18 \mathrm{fmol} / \mathrm{mg}$ protein. All Scatchard plots performed for $\left[{ }^{3} \mathrm{H}\right] \mathrm{NBI}$ showed monophasic profiles indicating the presence of only one class of binding sites.

Kinetic analyses performed for the binding of the adenosine receptor agonist $\left[{ }^{3} \mathrm{H}\right] \mathrm{CHA}$ to soluble guinea pig brain extracts are shown in Fig. 5. Saturable, specific binding of $\left[{ }^{3} \mathrm{H}\right] \mathrm{CHA}$, in contrast to $\left[{ }^{3} \mathrm{H}\right] \mathrm{NBI}$ binding, revealed biphasic Scatchard plot,

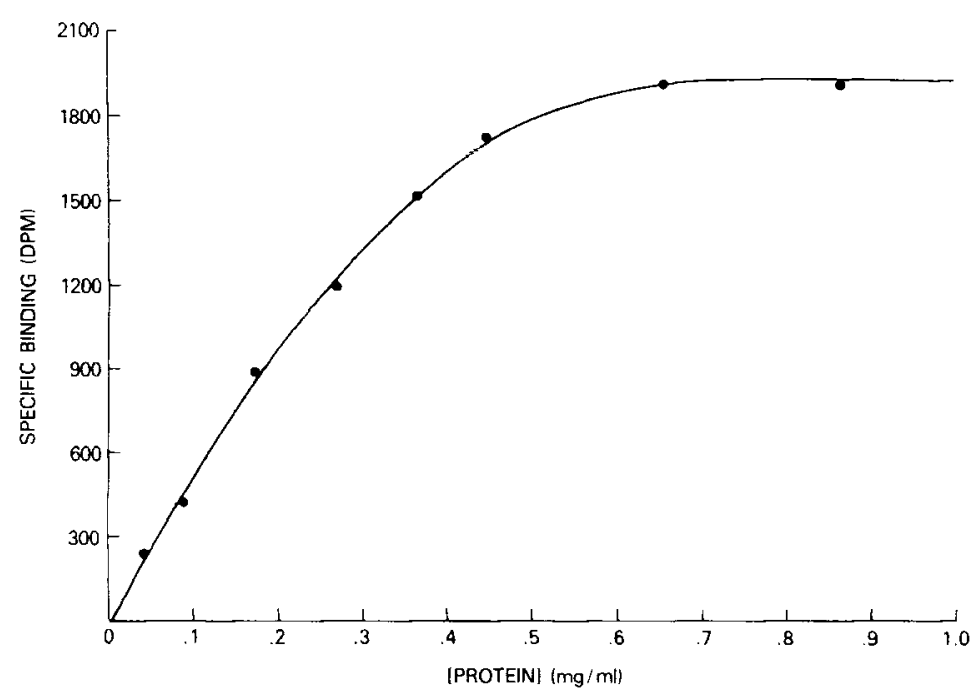

FIG. 1. Effect of protein concentration on the site-specific binding of $\left[{ }^{3} \mathrm{H}\right] \mathrm{NB} \mid$ to guinea pig soluble brain extracts. [ $\left.{ }^{3} \mathrm{H}\right] \mathrm{NBI}(0.7 \mathrm{nM})$ was incubated for $30 \mathrm{~min}$ at $22^{\circ} \mathrm{C}$ in $50 \mathrm{mM}$ Tris- $\mathrm{HCl}$ buffer $(\mathrm{pH} 7.5)$ adjusted to contain the indicated protein concentrations (abscissa) in the presence and absence of $5 \mu \mathrm{M} \mathrm{NBI}$. Site-specific binding of $\left[{ }^{3} \mathrm{H}\right] \mathrm{NBI}$ (ordinate) was determined as described in Materials and Methods. Each point is the average of two experiments performed in triplicate. 
FIG. 3. Reversibility of $\left[{ }^{3} \mathrm{H}\right] \mathrm{NB}$ binding to soluble guinea pig extracts. a: Solubilized extracts were incubated with $\left[{ }^{3} \mathrm{H}\right] \mathrm{NB}$ ! $(0.45 \mathrm{nM})$ with aliquots $(0.3 \mathrm{mg})$ filtered at the indicated times. Unlabeled NBI $(5 \mu M)$ was added at the point shown by the arrow; each data point is the total binding. The experiment was repeated three times with very similar results. b: Kinetic analysis of association of $\left[{ }^{3} \mathrm{H}\right] \mathrm{NBI}$ binding. c: Dissociation of $\left[{ }^{3} \mathrm{H}\right] \mathrm{NBI}$ binding. The dissociation constant $\left(k_{-1}\right)$ was calculated from the slope of the line in $c$ as $0.046 \mathrm{~min}^{-1}$. The rate of association $\left(k_{o b s}\right)$ was calculated from the slope of the line in $b$ as $0.143 \mathrm{~min}^{-1}$ and $K_{\mathrm{f}}$ was determined using the equation $K_{1}=\left(k_{\text {obs }}-k_{-1}\right) /\left[{ }^{3} \mathrm{H}\right] \mathrm{NBI}$ as $2.2 \times 10^{8} \mathrm{~min}^{-1} M^{-1}$. Beq represents specific binding at equilibrium and $B$ represents spe. cific binding at time $t$.
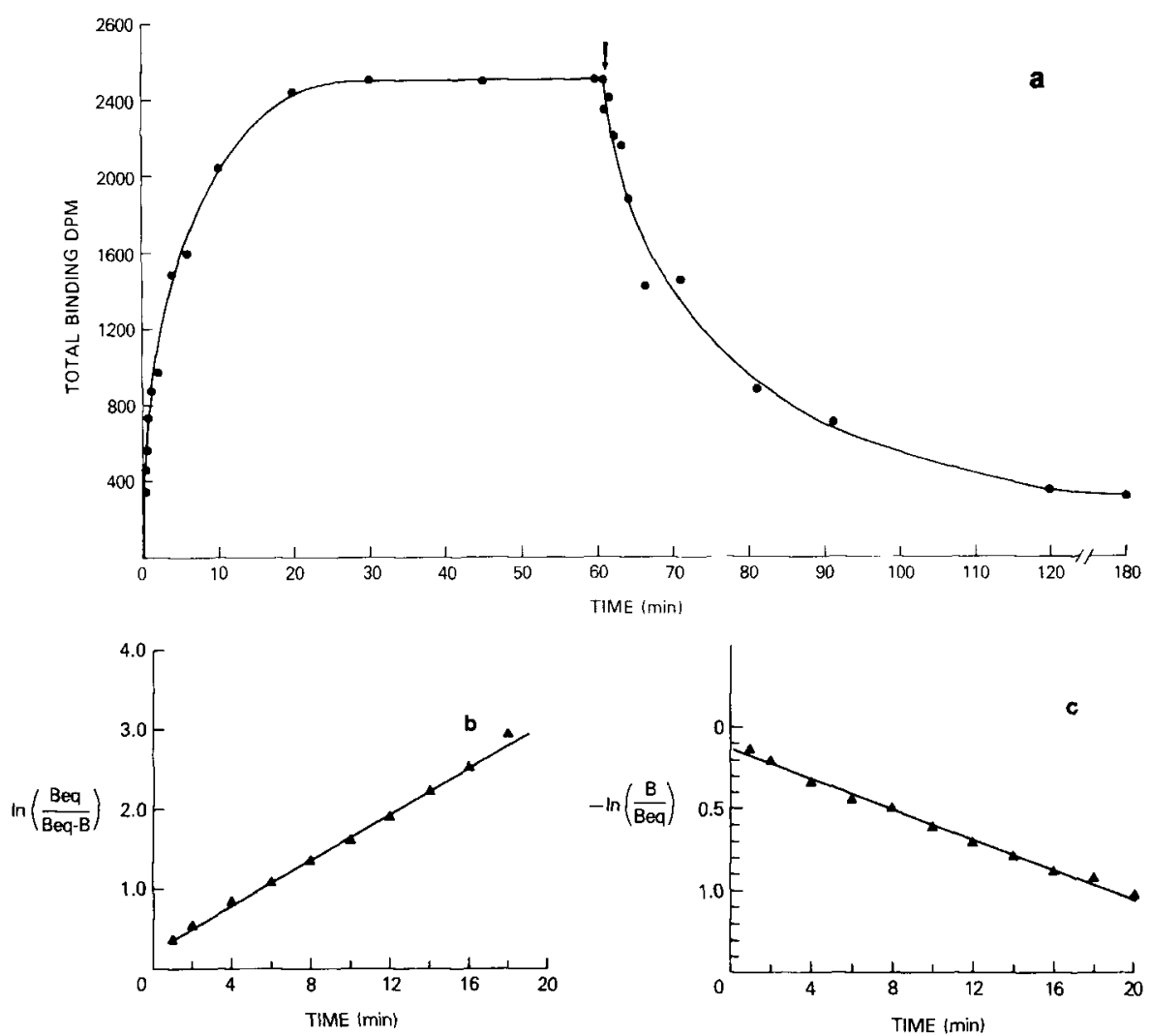

suggesting heterogeneous high- and low-affinity binding sites for $\left[{ }^{3} \mathrm{H}\right] \mathrm{CHA}$. Apparent $K_{\mathrm{D}}$ values for the two $\left[{ }^{3} \mathrm{H}\right] \mathrm{CHA}$ binding sites were $0.32 \pm 0.06$ $\mathrm{n} M$ and $5.50 \pm 0.52 \mathrm{n} M$, and $B_{\max }$ values were found to be $105 \pm 30$ and $300 \pm 55 \mathrm{fmol} / \mathrm{mg}$ protein, respectively. Preincubation of membrane pellets with adenosine deaminase prior to solubilization did not influence $\left[{ }^{3} \mathrm{H}\right] \mathrm{NBI}$ binding constants whereas $\left[{ }^{3} \mathrm{H}\right] \mathrm{CHA}$ binding showed a strict dependence on this procedure (data not shown).
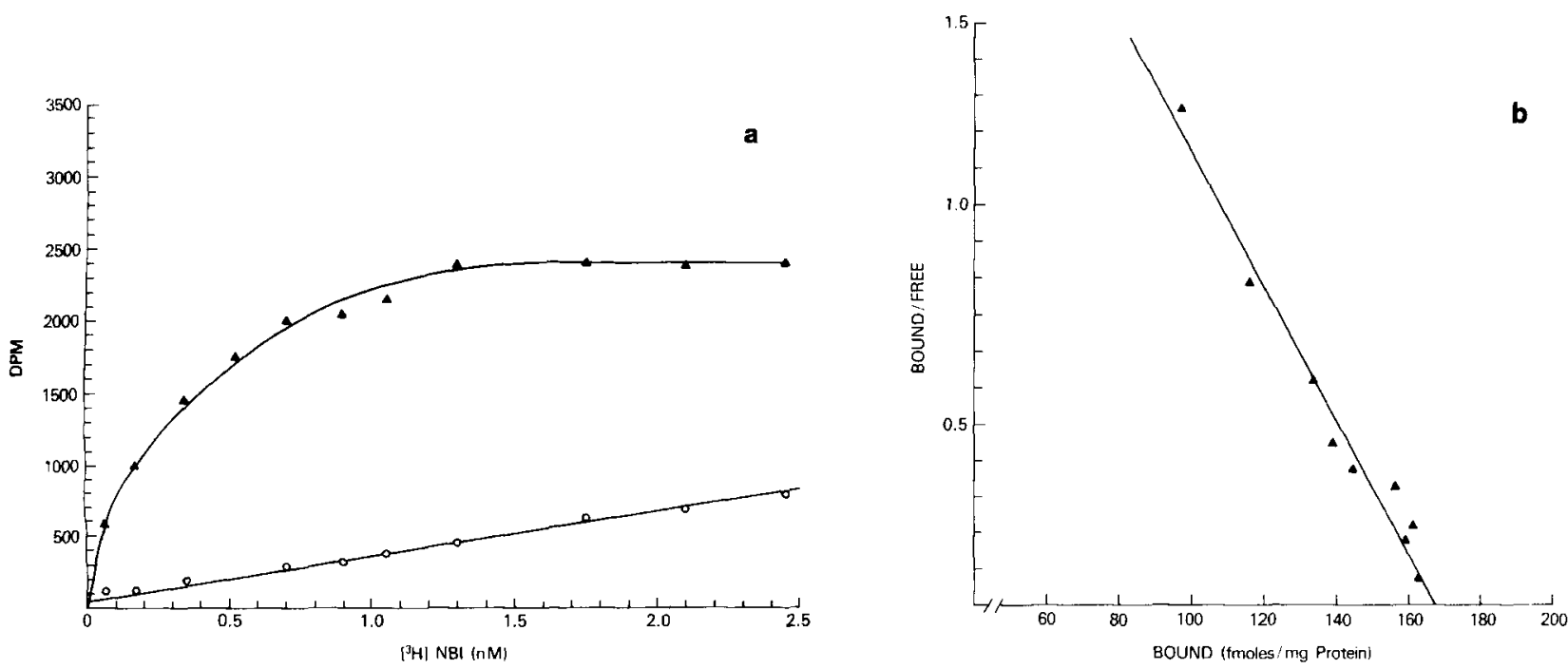

FIG. 4. Saturation isotherm and Scatchard plot for the binding of $\left[{ }^{3} \mathrm{H}\right] \mathrm{NBI}$ to soluble guinea pig brain sites. a: Soluble extracts $\left(0.4 \mathrm{mg} / \mathrm{ml}\right.$ protein) were incubated with graded concentrations of $\left[{ }^{3} \mathrm{H}\right] \mathrm{NBI}$ at $22^{\circ} \mathrm{C}$ in the absence and presence $(\mathrm{O})$ of $5 \mu M$ $\mathrm{NBI}$. Specific binding $(\mathbf{A})$ is defined as the total binding minus the nonspecific binding component. This plot is typically representative of eight similar experiments performed in triplicate. b: The Scatchard plot shows a single class of binding sites (linear regression line) with a $K_{\mathrm{D}}$ of $0.13 \mathrm{nM} \pm 0.06$ and a $B_{\max }$ of $150 \pm 35 \mathrm{fmol} / \mathrm{mg}$ protein. 

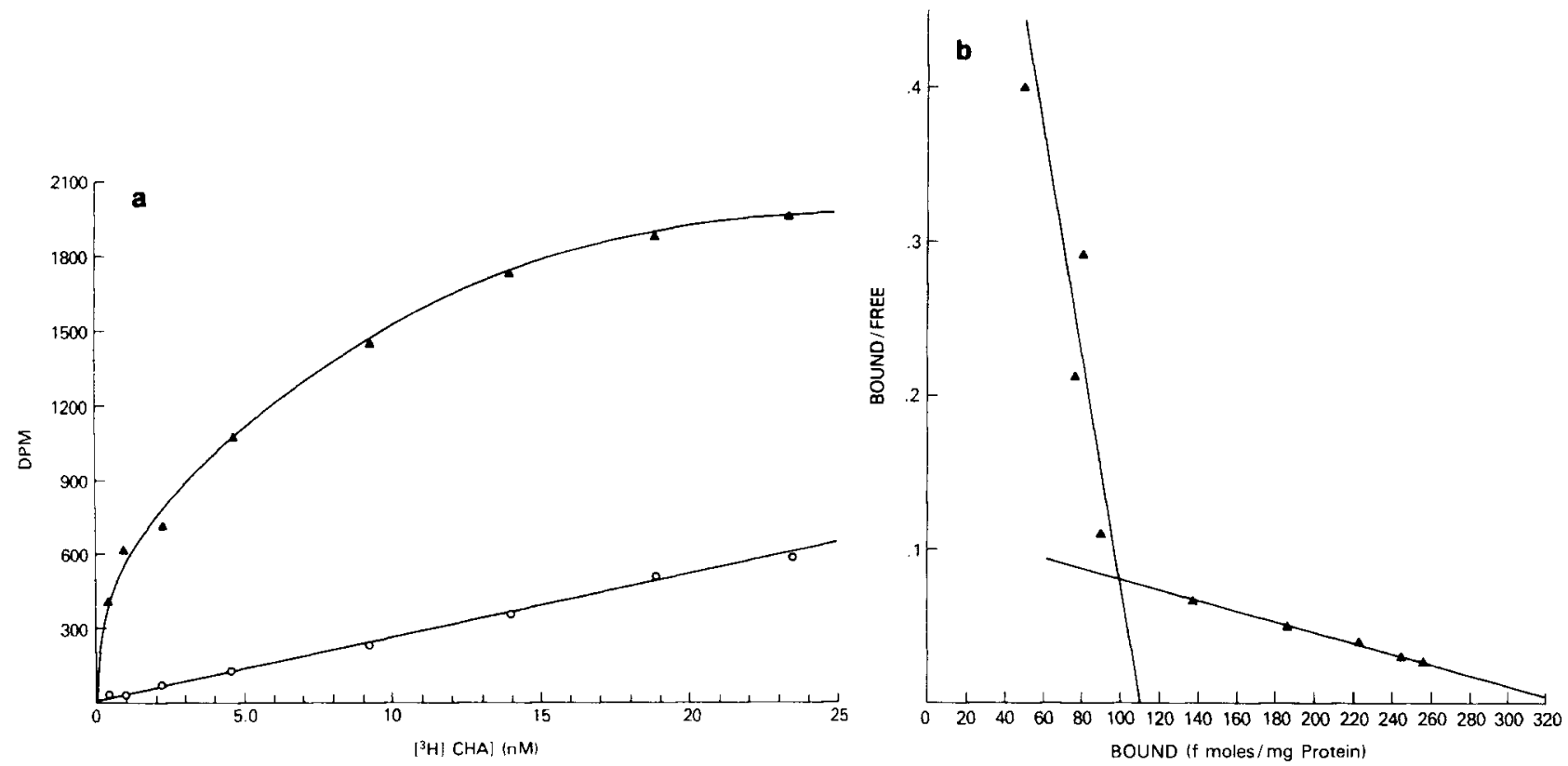

FIG. 5. Saturation isotherm and Scatchard plot for the binding of $\left[{ }^{3} \mathrm{H}\right] \mathrm{CHA}$ to soluble guinea pig brain sites. Soluble extracts $\left(0.4 \mathrm{mg} / \mathrm{ml}\right.$ protein) were incubated with graded concentrations of $\left[{ }^{3} \mathrm{H}\right] \mathrm{CHA}$ at $22^{\circ} \mathrm{C}$ and $\mathrm{pH} 7.5$. a: Specific (total minus nonspecific) and nonspecific binding is expressed in dpm. The saturation plot is typical of four experiments performed in triplicate b: The biphasic Scatchard plot is one of four experiments performed. $K_{D}$ values for the two soluble binding sites were determined to be $0.32 \pm 0.06 \mathrm{nM}$ and $5.5 \pm 0.52 \mathrm{nM}$. $B_{\max }$ values for the high- and low-affinity sites were $105 \pm 30 \mathrm{fmol} / \mathrm{mg} \mathrm{protein} \mathrm{and}$ $300 \pm 55 \mathrm{fmol} / \mathrm{mg}$ protein, respectively.

\section{Pharmacology of binding}

Table 1 shows the pharmacology of $\left[{ }^{3} \mathrm{H}\right] \mathrm{NBI}$ binding in rat and guinea pig brain extracts and that of $\left[{ }^{3} \mathrm{H}\right] \mathrm{CHA}$ binding in guinea pig brain extracts. NBI was a potent displacer of $\left[{ }^{3} \mathrm{H}\right] \mathrm{NBI}$ binding in both guinea pig and rat preparations with $K_{\mathrm{I}}$ values in the low nanomolar range. The potent adenosine uptake inhibitors dilazep, hexobendine, and dipyridamole were all powerful inhibitors of $\left[{ }^{3} \mathrm{H}\right] \mathrm{NBI}$ binding in guinea pig preparations with low nanomolar $K_{1}$ values. Of the three uptake inhibitors only dilazep was a potent displacer of binding in both rat and guinea pig extracts. Hexobendine and dipyridamole had a much lower affinity for the soluble rat sites showing $K_{1}$ values of 312.5 and 1,084 $\mathrm{nM}$, respectively. The order of potency of these compounds, however, was similar in both species (dilazep, hexobendine, dipyridamole).

Adenosine was a much poorer displacer of [ $\left.{ }^{3} \mathrm{H}\right] \mathrm{NBI}$ binding in both species with $K_{1}$ values in the high micromolar range. The adenosine receptor agonists CHA and L-PIA displayed $K_{\mathrm{I}}$ values of about $1 \mu M$ whereas caffeine was a very poor inhibitor in both species with $K_{1}$ values well above $400 \mu M$. Diazepam, a benzodiazepine, had low micromolar $K_{1}$ values in both species as did the dihydropyridine $\mathrm{Ca}^{2+}$ antagonist nimodipine. Verapamil, a nondihydropyridine $\mathrm{Ca}^{2+}$ antagonist, had a much lower affinity for $\left[{ }^{3} \mathrm{H}\right] \mathrm{NBI}$ sites than nimodipine.

In contrast to the $\left[{ }^{3} \mathrm{H}\right] \mathrm{NBI}$ binding site, the $\left[{ }^{3} \mathrm{H}\right] \mathrm{CHA}$ binding site in guinea pig preparations showed a high affinity for the adenosine analogs CHA and L-PIA with low nanomolar $K_{\mathrm{I}}$ values for these compounds. Of the adenosine uptake inhibitors, NBI was the strongest displacer of $\left[{ }^{3} \mathrm{H}\right] \mathrm{CHA}$ binding with a $K_{\mathrm{I}}$ value of $1.4 \mu \mathrm{M}$. The other uptake inhibitors tested showed much higher micromolar $K_{1}$ values as did the adenosine antagonist caffeine $(73 \mu M)$.

\section{DISCUSSION}

It is becoming quite clear that adenosine serves as a major modulator of physiologic function in the cardiovascular system (Berne, 1980) and in both the peripheral (Burnstock, 1975) and central nervous system (Phillis and $\mathrm{Wu}, 1981$ ). The ubiquitous presence of this purine, and its role in many metabolic processes has, however, made it difficult to characterize the mechanism of adenosine action in brain.

$\left[{ }^{3} \mathrm{H}\right] \mathrm{NBI}$ binding has been a useful probe for adenosine uptake sites in erythrocytes and HeLa cells because occupation of these sites by $\left[{ }^{3} \mathrm{H}\right] \mathrm{NBI}$ correlates well with inhibition of nucleoside transport and because this high-affinity binding is competitively displaced by other potent nucleoside transport inhibitors (Cass et al., 1974; Lauzon and Paterson. 1977: Jarvis and Young, 1980). Similar studies using rat brain tissue (Marangos et al., 1982) and guinea pig cerebral cortical tissue (Hammond 
TABLE 1. Pharmacology of $\left[{ }^{3} \mathrm{H}\right] \mathrm{NBI}$ and $\left[{ }^{3} \mathrm{H}\right] \mathrm{CHA}$ binding to soluble rat and guinea pig brain extracts

\begin{tabular}{|c|c|c|c|}
\hline \multirow[b]{2}{*}{ Inhibitor } & \multicolumn{2}{|c|}{$\left[{ }^{3} \mathrm{H}\right] \mathrm{NBI}\left(K_{\mathrm{I}}\right)$} & \multirow{2}{*}{$\frac{\left[{ }^{3} \mathrm{H}\right] \mathrm{CHA}(\mathrm{n} M)}{\text { Guinea pig }}$} \\
\hline & Rat & Guinea pig & \\
\hline \multicolumn{4}{|c|}{ Adenosine uptake inhibitors } \\
\hline NBI & $0.59=0.33$ & $1.86 \pm 0.44$ & $1,369 \pm 155$ \\
\hline Dilazep & $37.5 \pm 5.6$ & $11.46 \pm 3.61$ & $52,885 \pm 6,799$ \\
\hline Hexobendine & $312.5 \pm 103.2$ & $31.30 \pm 4.62$ & $105,769 \pm 13,598$ \\
\hline Dipyridamole & $1,084=110$ & $36.12 \pm 7.56$ & $51,923+8,159$ \\
\hline \multicolumn{4}{|c|}{ Adenosine and analogs } \\
\hline Adenosine & $92,000 \pm 1,500$ & $87,900 \pm 1,700$ & \\
\hline $\mathrm{CHA}$ & $739.6 \pm 77.34$ & $726.56 \pm 77.34$ & $5.00 \pm 1.02$ \\
\hline L-PIA & $968.8 \pm 31.3$ & $950 \pm 17.5$ & $6.41 \pm 1.11$ \\
\hline Caffeine & 400,000 & 400,000 & $73.100 \pm 21,000$ \\
\hline \multicolumn{4}{|l|}{ Benzodiazepines } \\
\hline Diazepam & $6,250 \pm 563$ & $9,200 \pm 1,350$ & \\
\hline \multicolumn{4}{|l|}{$\mathrm{Ca}^{2+}$ Antagonists } \\
\hline Nimodipine & $5.078 \pm 391$ & $6,075 \pm 550$ & \\
\hline Verapamil & $46,875 \pm 15,600$ & $39,500 \pm 4,700$ & \\
\hline
\end{tabular}

Inhibitory potency of various agents on the binding of $\left[{ }^{3} \mathrm{H}\right] \mathrm{NBI}$ and $\left[{ }^{3} \mathrm{H}\right] \mathrm{CHA}$ to solubilized brain sites. Inhibition of $\left[{ }^{3} \mathrm{H}\right] \mathrm{NBI}$ binding was performed in both rat and guinea pig preparations and that for $\left[{ }^{3} \mathrm{H}\right] \mathrm{CHA}$ in guinea pig alone. Six concentrations of each agent were tested for their effect on specific (total - nonspecific) binding of $\left[{ }^{3} \mathrm{H}\right] \mathrm{NBI}$ and $\left[{ }^{3} \mathrm{H}\right] \mathrm{CHA} . \mathrm{IC}_{50}$ values were determined from semilog plots and the $K_{\mathrm{I}}$ values derived as described in Materials and Methods. Each experiment was repeated three times with values representing means \pm SD.

and Clanachan, 1982, 1983) show $\left[{ }^{3} \mathrm{H}\right] \mathrm{NBI}$ to be a good probe for central adenosine uptake sites as well.

This study demonstrates that methods used to solubilize brain adenosine receptors (Bruns et al., 1983) can also be used to solubilize adenosine uptake sites from brain using $\left[{ }^{3} \mathrm{H}\right] \mathrm{NBI}$ as a probe. These sites, solubilized from guinea pig and rat brains, retain characteristics similar to those reported for $\left[{ }^{3} \mathrm{H}\right] \mathrm{NBI}$ binding sites in insoluble brain membrane preparations from these respective species (Hammond and Clanachan, 1982, 1983; Marangos et al., 1982).

Using the procedure described by Bruns et al. we obtained good yields of solubilized adenosine receptors and uptake sites. However, this procedure gave cloudy preparations due to the presence of glycerol in the solubilization buffer, and brought into question the solubility of the preparation. Even though our preparations were centrifuged at 145,000 $g$ for $1 \mathrm{~h}$, the density of glycerol in our samples affected the centrifugation process. Thus, it was uncertain whether the binding sites were solubilized. Removing glycerol from the solubilizing buffer gave us a clear preparation that still contained active binding sites but lost its activity rapidly. By extracting the sites without any glycerol and then reconstituting the supernatant with glycerol after the extraction, we were able to obtain clear, soluble preparations that were also stable. To ensure solubility, all extractions were passed through a 0.22 $\mu M$ filter before assaying. The use of glycerol in this manner was necessary for stability and is thus recommended for such extractions.

In the present study, we found that $\left[{ }^{3} \mathrm{H}\right] \mathrm{NBI}$ binding sites solubilized from rat and guinea pig brains had similar kinetic binding parameters. The binding was rapid in both cases and the $K_{\mathrm{D}}$ value for $\left[{ }^{3} \mathrm{H}\right] \mathrm{NBI}$ binding to rat brain extracts as determined by Scatchard mass law analysis $\left(K_{\mathrm{D}}=0.12\right.$ $\mathrm{n} M$ ) was similar to $K_{\mathrm{D}}$ values for guinea pig soluble sites as determined separately by Scatchard $\left(K_{\mathrm{D}}=\right.$ $0.13 \mathrm{n} M)$ and kinetic analyses $\left(K_{\mathrm{D}}=0.21 \mathrm{n} M\right)$. The total number of binding sites was similar in both cases (rat, $B_{\max }=133 \mathrm{fmol} / \mathrm{mg}$ protein; guinea pig, $B_{\max }=150 \mathrm{fmol} / \mathrm{mg}$ protein) and linear Scatchard plots indicated the presence of only one class of binding site in both species.

In binding displacement studies NBI was found to be the most potent inhibitor of $\left[{ }^{3} \mathrm{H}\right] \mathrm{NBI}$ binding to soluble extracts from both species. In guinea pig preparations the coronary vasodilators dilazep, hexobendine, and dipyridamole were all very potent, competitive inhibitors of $\left[{ }^{3} \mathrm{H}\right] \mathrm{NBI}$ binding. These compounds produce their dilatory effect via an inhibition of adenosine uptake leading to the accumulation of endogenous adenosine (Sano, 1974). The $K_{\mathrm{I}}$ values reported here for soluble guinea pig sites are similar to those reported for inhibition of $\left[{ }^{3} \mathrm{H}\right] \mathrm{NBI}$ binding in human erythrocytes (Clanachan et al., 1981), HeLa cells (Paterson et al., 1980), and dog heart and brain membrane preparations (Marangos et al., 1984). In rat brain soluble extracts, however, of the three adenosine uptake inhibitors, 
only dilazep was a strong displacer of $\left[{ }^{3} \mathrm{H}\right] \mathrm{NBI}$ binding. Hexobendine and dipyridamole maintained the low affinity for soluble rat $\left[{ }^{3} \mathrm{H}\right] \mathrm{NBI}$ binding sites that they display in rat insoluble brain membrane preparations (Marangos et al., 1982: Patel et al.. 1982b; Wu and Phillis, 1982). Although the reason for their markedly lower potency in rat brain is at present unclear, it is important to note that the order of potency of these uptake inhibitors for displacing $\left[{ }^{3} \mathrm{H}\right] \mathrm{NBI}$ binding (dilazep $>$ hexobendine $>$ dipyridamole) was the same in extractions from both species.

It has been suggested that part of the anxiolytic actions of the benzodiazepines may involve inhibition of adenosine uptake (Wu et al., 1981). In our soluble preparations diazepam, which has a very high affinity for benzodiazepine binding sites ( $K_{\mathrm{I}}$ value of $7.4 \mathrm{nM}$ ) (Mohler and Okada, 1978) showed a much lower affinity for the $\left[{ }^{3} \mathrm{H}\right] \mathrm{NBI}$ binding sites extracted from rat and guinea pig brains $\left(K_{1}\right.$ values of $6 \mu M$ and $9 \mu M$, respectively). These data suggest that if diazepam does indeed inhibit adenosine uptake, it probably does not do so by interacting at the adenosine uptake site that is labeled by NBI.

Conversely, in light of the discrepancies described in rat, compounds inhibiting $\left[{ }^{3} \mathrm{H}\right] \mathrm{NBI}$ binding should be examined for their effects on $\left[{ }^{3} \mathrm{H}\right]$ adenosine uptake as well. An opportunity to examine such a correlation is provided by dihydropyridine calcium antagonist drugs such as nimodipine. Although in our solubilized rat and guinea pig brain extractions nimodipine was only slightly better as an inhibitor of $\left[{ }^{3} \mathrm{H}\right] \mathrm{NBI}$ binding $\left(K_{\mathrm{I}}=5-\right.$ $6 \mu M$ ) than diazepam, this and other dihydropyridines have been shown to have nanomolar $K_{\mathrm{I}}$ values for $\left[{ }^{3} \mathrm{H}\right] \mathrm{NBI}$ sites in dog heart and brain (Marangos et al., 1984) and in human brain as well (Verma and Marangos, 1985). It will be interesting to examine the effect of these calcium antagonists on the uptake of $\left[{ }^{3} \mathrm{H}\right]$ adenosine as well as their ability to modulate adenosine action. Verapamil, a nondihydropyridine calcium antagonist was a far poorer inhibitor of $\left[{ }^{3} \mathrm{H}\right] \mathrm{NBI}$ binding.

NBI does not interact with the adenosine receptor (Marangos et al., 1982, 1983) and the adenosine analogs CHA and L-PIA showed poor affinity for soluble $\left[{ }^{3} \mathrm{H}\right] \mathrm{NBI}$ binding. In addition, when the binding of the adenosine agonist $\left[{ }^{3} \mathrm{H}\right] \mathrm{CHA}$ to soluble guinea pig brain extracts was examined, a much different kinetic profile was obtained than that for $\left[{ }^{3} \mathrm{H}\right] \mathrm{NBI}$ binding. $\left[{ }^{3} \mathrm{H}\right] \mathrm{CHA}$ is known to label adenosine $A_{1}$ receptor sites, and the biphasic Scatchard plot as well as the two $K_{\mathrm{D}}$ values determined for the low- and high-affinity soluble $\left[{ }^{3} \mathrm{H}\right] \mathrm{CHA}$ binding sites in our study are similar to those reported previously for insoluble rat brain preparations (Patel et al., 1982a; Marangos et al., 1983). L-PIA and CHA, in contrast to their poor action at the $\left[{ }^{3} \mathrm{H}\right] \mathrm{NBI}$ site, were found to be highly potent inhibitors of $\left[{ }^{3} \mathrm{H}\right] \mathrm{CHA}$ binding to soluble extractions. NBI and the other adenosine uptake inhibitors, on the other hand, were very poor displacers of $\left[{ }^{3} \mathrm{H}\right] \mathrm{CHA}$ binding. These data indicate that $\left[{ }^{3} \mathrm{H}\right] \mathrm{CHA}$ is a rather specific probe for the solubilized adenosine receptor, just as $\left[{ }^{3} \mathrm{H}\right] \mathrm{NBI}$ appears to be a very specific probe for solubilized adenosine uptake sites.

The availability of such distinct probes for adenosine receptors and uptake sites and the ability to use separate and simple assays to study both sites should greatly enhance the understanding of the adenosine system in brain as well as aid in the development of new drugs to affect this system. Solubilization of both sites as described in this study will help in the isolation and further characterization of these two sites.

Acknowledgment: The authors acknowledge the assistance of Sandra Coopersmith who prepared the manuscript.

\section{REFERENCES}

Barberis C., Minn A., and Gayet J. (1981) Adenosine transport into guinea pig synaptosomes. J. Neurochem. 36, 347-354.

Bender A. S., Wu P. H., and Phillis J. W. (1980) The characterization of $\left[{ }^{3} \mathrm{H}\right]$ adenosine uptake into rat cerebral cortical synaptosomes. J. Netwochem. 35, 629-640.

Berne R. M. (1980) The role of adenosine in the regulation of coronary blood flow. Circ. Res. 47, 807-813.

Brajeswar P., Chen M. F. and Paterson A. R. P. (1975) Inhibitors of nucleoside transport. A structure activity study using human erythrocytes. J. Med. Chem. 18, 968-973.

Bruns R. F. Daly J. W., and Snyder S. H. (1980) Adenosine receptors in brain membranes. Binding of $\mathrm{N}^{6}$ cyclohexyl$\left[{ }^{3} \mathrm{H}\right]$ adenosine and 1,3-diethyl-8- $\left[{ }^{3} \mathrm{H}\right]$ phenylxanthine. Proc. Natl. Acad. Sci, USA 77, 5547-5551.

Bruns R. F., Lawson-Wendling K.. and Pugsley T. A. (1983) A rapid filtration assay for soluble receptors using polyethylenimine-treated filters. Anal. Biochem. 132, 74-81.

Burnstock G. (1975) Purinergic transmission, in Handbook of Psychophamacology (Iversen L. L., Iverson S. D., and Snyder S. H.. eds). Vol. 5. pp. 131-194. Plenum Press, New York.

Cass C. E., Gaudette L. A., and Paterson A. R. P. (1974) Mediated transport of nucleosides in human erythrocytes. Specific binding of the inhibitor nitrobenzylthioinosine to nucleoside transport sites in the erythrocyte membrane. Biochim. Biophys. Acta 345, 1-10.

Clanachan A. S.. Hammond J. R., and Paterson A. R. P. (1981) Coronary vasodilator and benzodiazepine inhibition of site specific binding of nitrobenzylthioinosine, an inhibitor of nucleoside transport, to human erythrocytes. Br. J. Pharmacol. 74, 835 .

Crawley J. N., Patel J., and Marangos P. J. (1982) Behavioral characterization of two long-lasting adenosine analogs: sedative properties and interaction with diazepam. Life $S_{c i}$. 29, $2623-2630$.

Crawley J. N.. Patel J., and Marangos P. J. (1983) Adenosine uptake inhibitors potentiate the sedative effects of adenosine. Neurosci. Lett. 36, 169-174.

Daly J. W. (1979) Cyclic Nucleotides in the Nervous System. Plenum Press, New York.

Fredholm B. B. and Hedqvist P. (1980) Modulation of neurotransmission by purine nucleotides and nucleosides. Biochem. Pharmacol. 29, 1635-1643. 
Gavish M. . Goodman R. R., and Snyder S. H. (1982) Solubilized adenosine receptors in the brain: regulation by guanine nucleotides. Science 215, 1633-1635.

Hammond J. R. and Clanachan A. S. (1982) Benzodiazepines inhibit the binding of nitrobenzylthioinosine, a nucleoside transport inhibitor, to CNS membranes. Br. J. Pharmacol. 76,301 .

Hammond J. R. and Clanachan A. S. (1983) Inhibition of the site-specific binding of nitrobenzylthioinosine, an inhibitor of nucleoside transport, to CNS membranes, an International Sumposium on Adenosine (Berne R. M. and Rubio R., eds). Abstr. Martinus Nijhoff Medical Division. The Hague.

Hammond J. R., Jarvis S. M., Paterson A. R. P., and Clanachan A. S. (1983) Benzodiazepine inhibition of nucleoside transport in human erythrocytes. Biochem. Pharmacol. 32,12291235.

Haulica T., Aabei L., Benisteanu D., and Topoliceanu F. (1973) Preliminary data on the possible hypogenic role of adenosine. J. Neurochem. 21, 1019-1020.

Huang M. and Daly J. W. (1974) Adenosine-elicited accumulation of cyclic AMP in brain slices: potentiation by agents which inhibit uptake of adenosine. Life Sci. 14, 489-503.

Jarvis S. M. and Young, J. D. (1980) Nucleoside transport in human and sheep erythrocytes, evidence that nitrobenzylthioinosine binds specifically to functional nucleoside transport sites. Biochem. J. 190, 377-383.

Lauzon G. J. and Paterson A. R. P. (1977) Binding of the nucleoside transport inhibitor nitrobenzylthioinosine to HeLa cells. Mol. Pharmacol. 13, 883-891.

Marangos P. J., Patel J., Clark-Rosenberg R., and Martino A. M. (1982) $\left[{ }^{3} \mathrm{H}\right]$ Nitrobenzylthioinosine binding as a probe for the study of adenosine uptake sites in brain. J. Neurochem. 39, $184-191$.

Marangos P. J., Patel J., Martino A. M.. Dilli M., and Boulenger J. P. (1983) Differential binding properties of adenosine receptor agonists and antagonists in brain. J. Netrochem. 41, $367-374$.

Marangos P. J., Finkel M. S., Verna A., Maturi M. F., Patel J., and Paterson R. E. (1984) Adenosine uptake sites in dog heart and brain; interaction with calcium antagonists. Life Sci. 35, 1109-1116.

Mohler H. and Okada T. (1978) Biochemical identification of the site of action of benzodiazepines in human brain by $\left[{ }^{3} \mathrm{H}\right]$ diazepam binding. Life $S \mathrm{c} \cdot \mathrm{i} .22,985-996$.

Nakata H. and Fujisawa H. (1983) Solubilization and partial characterization of adenosine binding sites from rat brain stem. FEBS Lett. 158, 93-97.

Patel J., Newman M., and Mcllwain H. (1981) Cyclic AMP binding capacities and histone kinase activities in subcellular components of neocortical tissue. Biochem. J. 194, $621-626$.

Patel J., Marangos P. J., Stivers J., and Goodwin F. K. (1982a) Characterization of adenosine receptors in brain using $\mathrm{N}^{6}$ cyclohexyl[ $\left.{ }^{3} \mathrm{H}\right] \mathrm{adenosine.} \mathrm{Brain} \mathrm{Res.} \mathrm{237,} \mathrm{203-214.}$
Patel J., Marangos P. J., Skolnick P.. Paul S. M.. and Martino A. M. (1982b) Benzodiazepines are weak inhibitors of $\left[{ }^{3} \mathrm{H}\right] \mathrm{NBI}$ binding to adenosine uptake sites in brain. Netrrosci. Lett. 29, 79-82.

Paterson A. R. P. (1979) Adenosine transport, in Physiological and Regulatory Functions of Adenosine and Adenine Nucleotides (Baer H. P. and Drummond G. I., eds), pp. $305-$ 313. Raven Press, New York.

Paterson A. R. P., Lau E. Y., Dahlig E., and Cass C. E. (1980) A common basis for inhibition of nucleoside transport by dipyridamole and nitrobenzylthioinosine? Mol. Pharmacol. $18,40-44$.

Phillis J. W. and Wu P. H. (1981) The role of adenosine and its nucleotides in central synaptic transmission. Prog. Neurobiol. 16, 187-239.

Phillis J. W., and Wu P. H. (1983a) Role of adenosine and adenine nucleotides, in the central nervous system, in Physiology and Pharmacology of Adenosine Derivatives (Phillis J. W., Shimizu H., and Ui M., eds), pp. 219-237. Raven Press, New York.

Phillis J. W. and Wu P. H. (1983b) Nitrobenzylthioinosine inhibition of adenosine uptake in guinea pig brain. J. Pharm. Pharmacol. 35, 540.

Phillis J. W., Edstrom J. P., Kostopoulos G. K., and Kirkpatrick J. R. (1979) Effects of adenosine and adenine nucleotides on synaptic transmission in the cerebral cortex. Can. J. Physiol. Pharmacol. 57, 1289-1312.

Pickard M. A. and Paterson A. R. P. (1972) Use of 4-nitro benzyl-thioinosine in the measurement of rates of nucleoside transport in human erythrocytes. Can. J. Biochem. 50, $839-840$

Sano N. (1974) Enhancement of coronary vasodilating actions of adenosine by dilazep and dipyridamole in the dog. Jpn. J. Pharmacol. 24, 471-478.

Stone T. W. (1981) Physiological roles for adenosine and adenosine 5 ' triphosphate in the nervous system. Neuroscience $6,523-555$.

Van Calken D., Muller M.. and Hamprecht B. (1979) Adenosine regulates via two different types of receptors - the accumulation of cyclic AMP in cultured brain cells. J. Neurochem. 33, 999-1005.

Verma A., and Marangos P. J. (1985) Nitrobenzylthioinosine binding in brain: an interspecies study. Life Sci. 36, 283291.

Williams L. T., Mullikin D., and Leftkowitz R. J. (1976) Identification of $\alpha$-adrenergic receptors in uterine smooth muscle membranes by $\left[{ }^{3} \mathrm{H}\right]$ dihydroergocryptine binding. J. Biol. Chem. 251, 6915-6923.

Wu P. H. and Phillis J. W. (1982) Nucleoside transport in rat cerebral cortical synaptosomal membrane: a high affinity probe study. Int. J. Biochem. 14, 1101-1105.

Wu P. H., Phillis J. W., and Bender A. S. (1981) Do benzodiazepines bind at adenosine uptake sites in CNS? Life $S \mathrm{ci}$. $28,1023-1031$. 